\title{
Effects of BST and high energy diet on gene expression in mammary parenchyma of dairy heifers
}

\author{
Betina Joyce Lew ${ }^{1}$, Mauro Dal Secco de Oliveira ${ }^{2}$, José Esler de Freitas Júnior ${ }^{3}$, Marina Vieira \\ de Carvalho ${ }^{3}$, Aníbal Coutinho do Rêgo ${ }^{2}$, Francisco Palma Rennó ${ }^{3}$
}

\footnotetext{
${ }^{1}$ Department of Animal Science, Michigan State University, East Lansing, MI, USA.

${ }^{2}$ Departamento de Zootecnia, Universidade Estadual Paulista "Júlio de Mesquita Filho" - UNESP, Via de Acesso Prof. Paulo Donato Castellane s/n, CEP 14884-900, Jaboticabal, SP, Brazil.

${ }^{3}$ Departamento de Produção e Nutrição Animal, Faculdade de Medicina Veterinária e Zootecnia, Universidade de São Paulo (USP), Avenida Duque de Caxias Norte, 225 - Campus da USP, CEP: 13635-900, Pirassununga, SP, Brazil.
}

\begin{abstract}
The objective of this study was to determine the effects of dietary energy and recombinant bovine somatotropin (bST) injection to identify genes that might control mammogenesis. Total RNA was extracted from the parenchymal tissue of 32 heifers randomly assigned to one of four treatments: two diets (a standard diet and a high energy, high protein diet), each with or without bST. To perform microarray experiments, RNA samples were pooled ( 2 animals/pool) before reverse transcription and labeling with Cy3 or Cy5. A 4-node loop design was used to examine the differential gene expression among treatments using a bovine-specific cDNA microarray (National Bovine Functional Genomics Consortium Library, NBFGC) containing 18,263 unique expressed sequence tags (EST). Significance levels of differential gene expression among treatments were assessed using a mixed model approach. Injection of bST altered the expression of $12 \%$ of the genes on NBFGC slide related to tissue development, whereas $6 \%$ were altered by diet. Administration of bST increases the expression of genes positively related to cell proliferation and mammary parenchyma to a greater extent than a high energy diet.
\end{abstract}

Key Words: gene regulation, mammary gland development, microarray, nutrition, somatotropin

\section{Introduction}

The establishment of milk yield potential is critically determined during the prepubertal phase of mammary development (Sejrsen \& Purup, 1997). A complex process involving environmental factors such as photoperiod and diet, the endocrine system, and stimulatory and inhibitory autocrine/paracrine factors regulates mammary development (Forsyth, 1989). It is well accepted that nutrition plays an important role in mammary development and subsequent milk production. Several reports have shown that feeding heifers with high-energy diets during the prepubertal period is detrimental to mammary development, with subsequent permanent reduction in milk production (Sejrsen \& Purup, 1997). However, Radcliff et al. (1997) did not find a decrease in mammary parenchymal tissue mass or DNA when prepubertal heifers were fed high energy diets combined with high protein levels. In a subsequent experiment, animals fed the same prepubertal diet produced $14 \%$ less milk during first lactation when compared with animals receiving a standard diet (Radcliff et al., 2000).
Administration of bST to prepubertal dairy heifers increases growth rates and decreases carcass fat (Bauman et al., 1991; Vestergaard et al., 1993). In mammary tissue, bST treatment increases the total mass of parenchyma, and the amount of parenchymal DNA and RNA decreases the mass of adipose tissue (Sejrsen et al., 1986; Radcliff et al., 1997) Despite the many studies that have examined effects of diet or bST on mammary development, very little is understood about the possible mechanisms that mediate effects of heifer management on mammary cell proliferation and subsequent milk production. The development of microarray technology (Suchyta et al., 2003) has made it possible to examine a large number of genes that are being differentially expressed in different situations. Identification of new genes related to cell proliferation can lead to a better characterization of autocrine and paracrine factors involved in the process of mammary gland development.

The objective of the present study was to determine the effects of feeding a diet with increased energy and protein with or without bST injection on the gene expression profile of mammary parenchymal tissue of prepubertal heifers and to identify genes that control mammogenesis, and which can be altered by these managements. 


\section{Material and Methods}

The tissue used in the present study was collected in a previous experiment conducted in 1994 at Michigan State University. Animal management, diet and tissue collection are described in detail in Radcliff et al. (1997). Briefly, thirty-two Holstein heifers, average body weight (BW) of $126 \mathrm{~kg}$, were randomly assigned to one of four treatments from 4 months of age until slaughter at the luteal phase of the fifth estrous cycle, which is on average 71 days after puberty onset. Low-control (LC) animals were fed a total mixed diet formulated to produce an average daily gain of $0.8 \mathrm{~kg} \mathrm{BW} / \mathrm{d}$. High-control (HC) animals were fed a total mixed diet with elevated protein and energy formulated to produce an average daily gain of $1.2 \mathrm{~kg} \mathrm{BW} / \mathrm{d}$. Low-bST (LB) animals were fed the low-control diet and received a daily injection of $25 \mu \mathrm{g}$ of bST/kg of BW (Pfizer Animal Health, Pharmacia and Upjohn Inc., Kalamazoo, MI), and high-bST (HB) animals were fed the high energy diet and daily injected $25 \mu \mathrm{g}$ of bST $/ \mathrm{kg}$ of BW. All injections were intramuscular. At slaughter, samples of mammary parenchyma and mammary adipose tissue were collected and stored at $-80{ }^{\circ} \mathrm{C}$.

Total RNA was isolated from $100 \mathrm{mg}$ parenchymal tissue of 32 animals (8/treatment) using Ribopure kit (Ambion). After isolation, the RNA concentration was determined by measuring absorbance at $260 \mathrm{~nm}$; RNA solution was precipitated for at least one hour at $-20{ }^{\circ} \mathrm{C}$ and washed with $75 \%$ ethanol. Dry pellet of RNA was then suspended in a previously calculated volume of RNAse-free MiliQ water to reach a minimum concentration of $1.25 \mu \mathrm{g} / \mu \mathrm{l}$, based on first spectrophotometer measurements. A new spectrophotometer evaluation was performed in order to check final concentration of RNA. To check quality, $1.0 \mu \mathrm{l}$ of RNA sample containing 100 to 500 ng RNA was analyzed with Bioanalyzer 2100 (Agilent Technologies, Palo Alto, CA), and RNA quality was considered acceptable if the ratio between peaks for the $28 \mathrm{~S}$ and $18 \mathrm{~S}$ rRNA was $\geq 0.9$. Samples were then stored at $-80{ }^{\circ} \mathrm{C}$ until microarray analysis was performed.

The experiment was conducted in a $2 \times 2$ factorial arrangement, with two different diets (low or high energy and protein levels, denoted by $\mathrm{L}$ and $\mathrm{H}$ respectively), with or without bST (represented by B and C, respectively). Total RNA samples were pooled ( 2 samples/pool) to generate a total of 16 pooled samples, four per treatment. The microarray experiment consisted of four independent loops, each with different ordering and labeling of treatments so that all six possible different combinations $(\mathrm{LC} \times \mathrm{HC}$; $\mathrm{LC} \times \mathrm{LB} ; \mathrm{HC} \times \mathrm{HB} ; \mathrm{LB} \times \mathrm{HB} ; \mathrm{LC} \times \mathrm{HB}, \mathrm{HC} \times \mathrm{LB}$ ) were represented at least once in both directions.
The National Bovine Functional Genomic Consortium (NBFGC) library containing 18,263 unique expressed sequence tags (EST) was used for microarray experiments. Library description and microarray protocol were previously detailed by Suchyta et al. (2003). Total RNA $(10 \mu \mathrm{g})$ was used as template in reverse transcription reaction with Atlas PowerScript Fluorescence Labeling system (BD Bioscences, Alameda, CA) with oligo $(\mathrm{dT})_{18}$ as primer. Following first-strand synthesis and prior to hybridization, cDNA were labeled using n-hydroxisuccinate (NHS)derivatized $\mathrm{Cy} 3$ and $\mathrm{Cy} 5$ dyes (Amersham Bioscencies). The hybridization process was performed at GeneTAC Hybridization Station (Genomic Solutions, Ann Arbor, MI), with temperatures varying from 42 to $65^{\circ} \mathrm{C}$, for 18 hours in vacuo. After hybridization and washing with medium and high stringency buffer (Genomic Solutions), slides were rinsed briefly at room temperature in $2 \mathrm{X} \mathrm{SSC}$ and $1 \mathrm{X}$ in double-distilled $\mathrm{H}_{2} \mathrm{O}$ and dried by centrifugation at $300 \times \mathrm{g}$ at room temperature for $2 \mathrm{~min}$ inside $50 \mathrm{~mL}$ conical tubes. Dried slides were scanned immediately in a GeneTAC LS IV microarray scanner (Genomic Solutions).

GeneTAC integrator 4.0 software was used to process array images, align spots, and integrate robot-spotting files with the microarray images and export intensity data. The final report was retrieved as raw spot intensities in commaseparated value files, compatible with Microsoft Excel and SAS (Statistical Analysis System, version 8).

Array-specific data normalization was performed using a robust local regression technique (Cleveland \& Grosse, 1991) with the LOESS procedure of SAS (Statistical Analysis System, version 8). The efficiency of LOESS normalization was assessed by monitoring Mus-A plots (Yang et al., 2002) and $\log C y 3$ versus $\log C y 5$ scatter plots for data from each array before and after normalization. The normalized data were then back transformed prior to further statistical analyses using the formula: $\log C y 3^{*}=A+M^{*} / 2$ and $\log C y 5^{*}=A-M^{*} / 2$, where $\log C y 3^{*}$ and $\log C y 5^{*}$ are the normalized $\log$ intensities. Here, $M^{*}=M-\hat{M}$ represents each of the normalized $M$ values, with $\hat{M}=$ LOESS predicted value for each spot. Log intensities adjusted via LOESS were then analyzed statistically using a mixed model approach consisting of two steps (Wolfinger et al., 2001). The first step involved array-specific spatial variability normalization and the second step, gene-specific analyses to test the effect of diet and bST on expression profiles for individual genes. The normalization model in the first step included the overall effects of treatments, arrays, pools, dye, and patch within array. The second step of the statistical analysis consisted of gene-specific models for the estimated residuals obtained from the normalization 
approach described above. For each gene, a linear mixed model was considered, including the fixed effects of diet, $\mathrm{bST}$, the interaction between them and the effect of dye, as well as the random effects of replication (pools), array and residual effects. The P-values from these tests were converted to q-values to establish statistical significance based on a false discovery rate (FDR) of 5\% for multiple testing (Storey, 2002). The analyses were computed by using the MIXED procedure of SAS (Statistical Analysis System, version 8).

Next, the spotted cDNA sequences representing genes whose expression profiles varied significantly across time were subjected to BLASTN analysis to reveal identities, and the functions of these genes were determined through an extensive PubMed literature search. This information was used to form preliminary clustering of affected genes into broad functional categories for presentation in the results.

\section{Results and Discussion}

Heifers in groups LC and LB were slaughtered approximately $276 \mathrm{~d}$ after the beginning of the experiment, while animals in groups $\mathrm{HC}$ and $\mathrm{HB}$ were slaughtered after around $218 \mathrm{~d}$. Treatments resulted in gains of $0.77 \mathrm{~kg} \mathrm{BW} / \mathrm{d}$ (group LC); $0.85 \mathrm{~kg} \mathrm{BW/d} \mathrm{(group} \mathrm{LB);} 1.19 \mathrm{~kg} \mathrm{BW/d}$ (group $\mathrm{HC}$ ) and $1.27 \mathrm{~kg} \mathrm{BW} / \mathrm{d}$ (group HB).

Within main contrasts $(\mathrm{B} \times \mathrm{C}, \mathrm{H} \times \mathrm{L}), 1083$ genes were differentially expressed $(\mathrm{P}<0.05)$. The bST injection altered the expression of 620 genes, while high energy andprotein diet altered the expression of 463 genes $(\mathrm{P}<0.05)$. There are multiple ways to explore biological significance of results obtained in microarray experiments. One option is to organize the genes into functional groups of signaling pathways, to examine the regulation of clusters of genes. The authors of the present study aimed at identifying bST and/or high-energy diet-regulated genes, involved in the induction or inhibition of parenchymal tissue development.

Four hundred and forty-eight genes in NBFGC library were putatively identified as related to inhibition of tissue development, according to their biological or molecular functions in gene ontology (GO) data base. Genes with function related to cell cycle, cell adhesion, cell proliferation and cell growth were considered positively related to tissue development (proliferative genes), while genes related to cell death, apoptosis, cell cycle arrest and negative regulation of cell proliferation were considered inhibitors of tissue development (anti-proliferative genes).
Regardless of diet, bST injection altered the expression of $53(11.8 \%)$ genes related to tissue development, upregulating the expression of 34 proliferative genes (Tables 1 and 2) and only two (DEAD-box protein abstrakt (ABS) and Growth-arrest specific 8) anti-proliferative genes $(\mathrm{P}<0.05)$ (Table 3). Seventeen genes were down-regulated by the bST treatment $(\mathrm{P}<0.05$; Tables 1,2 and 3$)$; six of them were classified as anti-proliferative genes (insulinlike growth factor binding protein 3 - IGFBP3; caspase recruitment domain family, member 11; inhibitor of kappa light polypeptide gene enhancer in B-cells, kinase gamma; interleukin 2 receptor; and interleukin 18BRCA1-associated protein-1 (ubiquitin carboxy-terminal hydrolase)) (Table 3).

On the other hand, only $26(5.7 \%)$ genes related to tissue development were altered by diet, stimulating the expression of 14 proliferative genes (Table 4) and two antiproliferative genes (Table 5); and inhibiting the expression of 10 proliferative genes (Table 4; Figure 1).

Radcliff et al. (1997) reported that administration of bST increased parenchymal weight and DNA content of the mammary gland by $47 \%$, when compared with noninjected control animals, suggesting that bST stimulates proliferation of mammary parenchymal cells. In the present work, several novel bST-regulated proliferative genes were identified (Tables 2 and 3).

In the present study, bST increased mRNA for insulinlike growth factor 1 (IGF-I) in liver and serum concentration of IGF-1, as previously reported by Radcliff et al. (2004), but did not alter IGF-1 mRNA in the parenchymal tissue. Treatment with bST reduced the abundance of mRNA for IGFBP3 in mammary tissue $(\mathrm{P}<0.01)$, which is consistent with previous findings (Berry et al., 2001).

Since IGFBP3 is negatively associated with cell proliferation (Huynh et al., 1996) down-regulation of IGFBP3 mRNA could increase the number of epithelial cells, because it would increase the amount of IGF-I available to the epithelial cell receptors. Moreover, an IGF-1

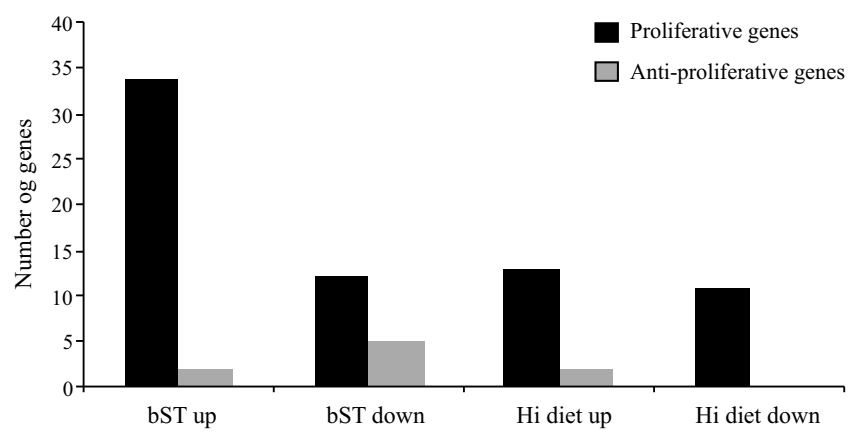

Figure 1 - Number of proliferative and anti-proliferative genes altered by diet and bST administration $(\mathrm{P}<0.05)$ 


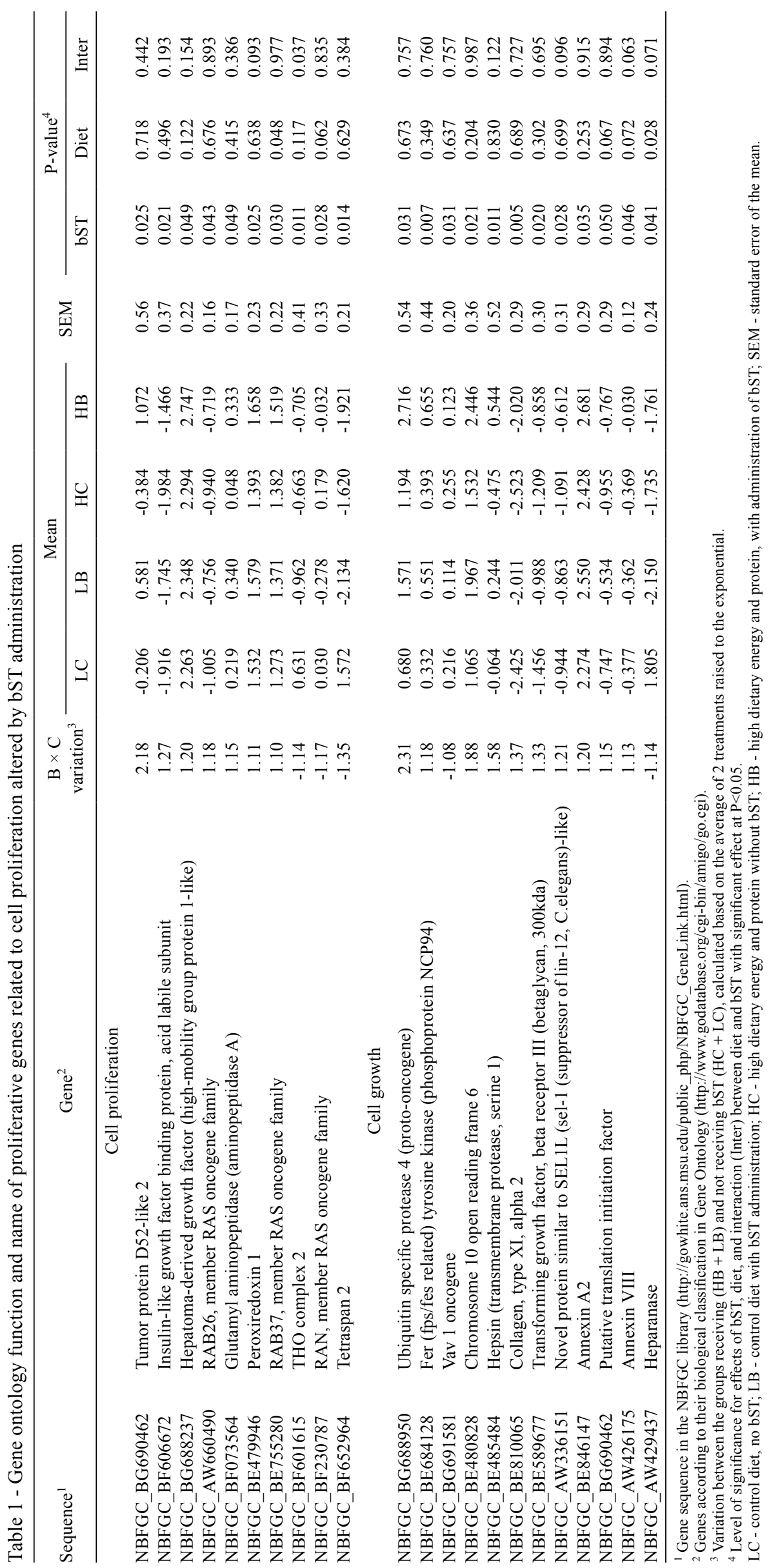




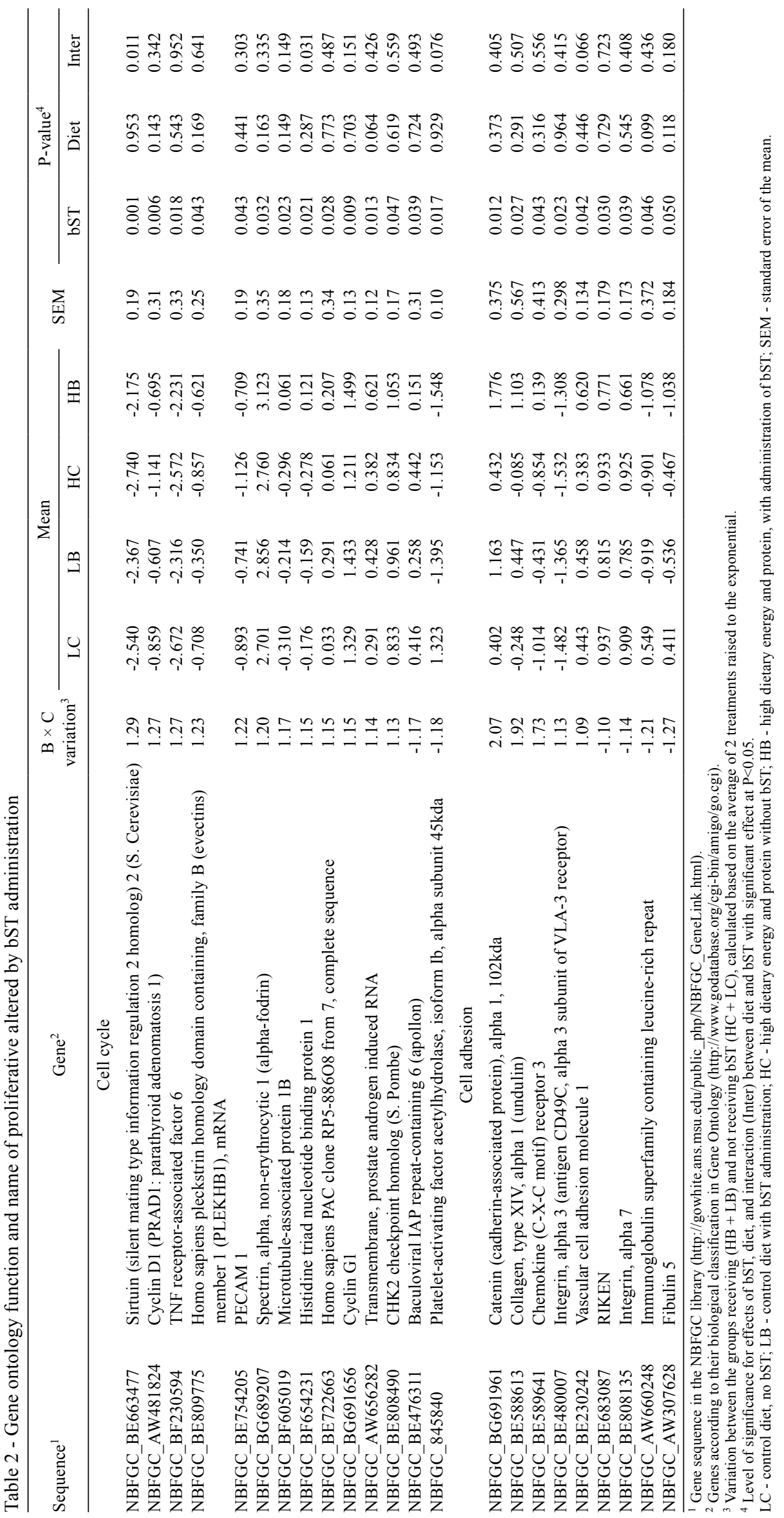


independent effect was also postulated for IGFBP3 (Akers et al., 2000), since the addition of this protein blocked the mitogenic effects of mammary extracts, thus a direct effect of the decrease in IGFB3 should be considered.

Somatotropin altered the expression of 9 genes related to cell adhesion. Cell adhesion (Table 2) primarily depends on the cadherin and integrin families of molecules, acting on segregation, sorting, rearrangements and migration of cell populations, and providing the basis for the dynamic morphogenetic processes of tissue formation (Steinberg, 1996). In the mammary gland, the epithelial type of adherent junction is composed of the E-cadherin/ catenin complex. This complex consists of transmembrane E-cadherin and its associated intracellular catenins $(\alpha, \beta$, $\gamma$ and p120). The extracellular region of E-cadherin is responsible for homotypic interactions facilitating cellcell connections, while the cytoplasmic domain of E-cadherin binds to $\beta$-catenin. Beta-catenin binds to $\alpha$-catenin, which is required to anchor the cadherin complex to the actin cytoskeleton (Beavon, 2000).

The mammary gland expresses $\alpha$-catenin during all stages of development, and the biogenesis of a functional mammary gland depends on the presence of this molecule. Alpha-Catenin is needed for normal mammary cell adhesion, polarization, stabilization and functioning (Nemade et al., 2004). In the present study, bST increased the expression of $\alpha$-catenin mRNA by $100 \%$, compared to bST control animals $(\mathrm{P}<0.02$; Table 2$)$. One reason for the increased $\alpha$-catenin might be the involvement of this molecule in IGF-1-induced cell-migration (André et al., $2004)$; conversely, $\alpha$-catenin might be directly involved in the IGF-1 signaling pathway, since the loss of $\alpha$-catenin alters the response of keratinocytes to several growth factors (Vasioukhin et al., 2001).

Interestingly, the increase in $\alpha$-catenin mRNA was coincident with an increase in the platelet-endothelial-cell adhesion molecule (PECAM-1) $(\mathrm{P}<0.05$; Table 2). PECAM-1 is a glycoprotein belonging to the immunoglobulin superfamily of cell-adhesion molecules expressed in endothelial cells, platelets and specific cells of the immune system (Ilan \& Madri, 2003). Lack of PECAM-1 expression in transgenic virgin mice led to impairment in mammary ductal branching morphogenesis and decrease in ductal epithelial cell proliferation (Ilan et al., 2001). Evidence suggests that this effect occurs through interactions with molecules of the STAT system and catenin complex (Ilan et al., 2001). Moreover, PECAM-1 promoted $\beta$-catenin accumulation and stimulated cell proliferation (Biswas et al., 2003). The findings of our work, demonstrating that bST-treated animals had increased expression of both PECAM- 1 and $\alpha$-catenin 


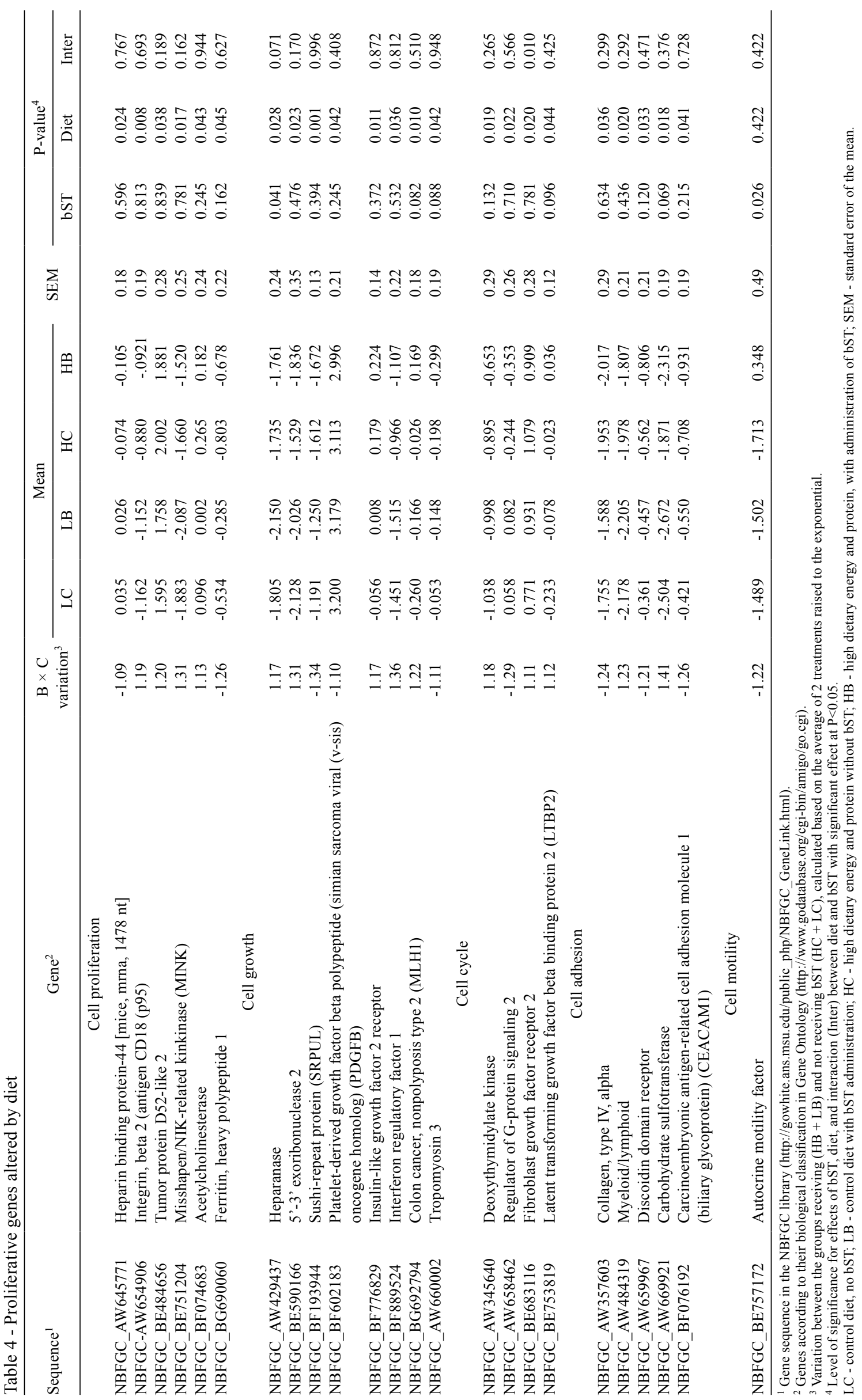


mRNA, suggest a novel mechanism for somatotropin actions in mammary development involving those molecules.

Another interesting molecule, stimulated by bST administration, was serine protease hepsin (Table 1) $(\mathrm{P}<0.02)$. Hepsin is a type II transmembrane serine protease found in significant levels in many different types of mammalian cells (Tsuji et al., 1991; Torres-Rosado et al., 1993). Proteases are present during cell migration and tissue rearrangement during morphogenesis, creating space for cell migration and promoting extension of epithelial cells through the extracellular matrix (Saksela \& Rifkin, 1988).

Serine proteases are known to have growth factorlike activity (Fenton, 1986) and hepsin seems to be indispensable for cell growth and for maintenance of normal cell morphology (Torres-Rosado et al., 1993).

The increase in hepsin mRNA, observed in this study, suggests that this serine protease is somehow involved in bST-stimulation of mammary parenchyma development. The mechanisms by which proteases stimulate cell growth and proliferation are not totally clear. Other proteases, such as the prostate specific-antigen (PSA), were shown to be involved in IGF-I pathway by cleaving the IGFBP3 molecule and lowering its affinity for IGF-1, allowing IGF-1 to bind to its membrane receptor on benign prostate hyperplasia (BPH) epithelial cells (Cohen et al., 1992). Moreover, Sutkowski et al. (1999) found that proteases attenuated the inhibitory effects of IGFBP-3 in BPHderived stromal cells in vitro, and PSA stimulated the growth of those cells by $17 \%$.

An alternative proliferative response might result from protease binding to specific cell-surface receptors (Vu et al., 1991). Proteases may also work as autocrine growth factors on the surrounding responsive epithelial cells, as in vitro experiments have demonstrated both direct and indirect growth responses in normal and neoplasic prostate epithelial cells to proteases such as PSA (Cohen et al., 1992). Overexpression of hepsin by bST injection suggests that this protease might participate in stimulation of mammary parenchymal growth.

In addition, somatotropin injection up-regulated the expression of several genes involved in cell proliferation (such as the tumor protein D52 and the hepatoma-derived growth factor), two different types of collagen, genes involved in cell adhesion (Table 1), genes involved in cell cycle progression, such as cycle D1 and cycle G1 (Table 2), proteases involved in the acceleration of the G1 phase of the cell cycle, and in the transition grom the G1 to the S phase of the cell cycle (Motokura et al., 1991). Somatotropin also down-regulated the expression of some genes related to 
apoptosis such as interleukin 18 and interleukin 2 receptor (Table 3)

High-energy diet altered the expression of only $5.7 \%$ of the genes in NBFGC library, related to tissue development $(\mathrm{P}<0.05)$ (Tables 4 and 5). However, the NBFGC library evaluates more than 18,000 genes at a time, and may not be so efficient in the detection of specific genes alterations. Therefore, a possibly higher effect of diet should not be totally discarded, and it is important that future studies apply more precise techniques to evaluate more subtle variations that may have not been identified.

Results of this study suggest that there was no detrimental effect of high-energy high-protein diet on mammary parenchyma development, and Radcliff et al. (1997), analyzing the same samples, reported that the high-energy diet did not reduce cell number or metabolic activity of the mammary gland.

However, Davis Rinker et al. (2008) reported that increasing dietary energy intake of weaned prepubertal heifers inhibits mammary growth, relative to body growth, in a time-dependent manner, and when used for a longer duration, it linearly decreased the mass of fat-free mammary parenchymal tissue. The authors also observed a linear reduction in the percentage of proliferating epithelial cells, which is consistent with the idea that high energy diets reduce the mammary parenchymal mass at puberty. In this regard, Radcliff et al. (2000) observed a 14\% reduction in milk production in the first lactation of heifers fed diets with high energy and high protein levels.

On the other hand, Brown et al. (2005) reported that increasing energy and protein intake in Holstein heifer calves from 2 to 8 weeks of age can increase the rate of mammary parenchyma development, but it is not clear if this would increase milk production later in life.

\section{Conclusions}

Treatment with bST alters the expression of several genes related to parenchymal development, including growth factors and molecules involved in the cell cycle, cell adhesion, cell-to-cell communication, components of extra cellular matrix, cell growth and cell proliferation. Future studies should explore the involvement of these genes in mediating the mammogenic response of the recombinant bovine somatotropin. In contrast, feeding a high energy and protein diet altered few genes in mammary parenchyma, consistent with the lack of a direct negative effect of highenergy treatment on mammary parenchyma development in these heifers.

\section{Acknowledgments}

Thanks to Professors James Liesman and Michael John VandeHaar from University of Michigan, in The United States of America, for the resources provided for the project and scientific support in conducting this study.

\section{References}

AKERS, R.M.; MCFADDEN, T.B.; PURUP, S. et al. Local IGF-I axis in peripubertal ruminant mammary development. Journal of Mammary Gland Biology and Neoplasia, v.5, p.43-51, 2000.

ANDRE, F.; JANSSENS, B.; BRUYNEEL, E. et al. Alpha-catenin is required for IGF-I-induced cellular migration but not invasion in human colonic cancer cells. Oncogene, v.23, p.1177-1186, 2004.

BAUMAN, D.E. Bovine somatotropin: review of an emerging animal technology. Journal of Dairy Science, v.74, p.3913-3932, 1991.

BEAVON, I.R. The E-cadherin-catenin complex in tumour metastasis: structure, function and regulation. European Journal of Cancer, v.36, p.1607-1620, 2000.

BERRY, S.D.; MCFADDEN, T.B.; PEARSON, R.E. et al. A local increase in the mammary IGF-1:IGFBP-3 ratio mediates the mammogenic effects of estrogen and growth hormone. Domestic Animal Endocrinology, v.21, p.39-53, 2001.

BISWAS, P.; CANOSA, S.; SCHOENFELD, J. et al. PECAM-1 promotes beta-catenin accumulation and stimulates endothelial cell proliferation. Biochemical and Biophysical Research Communications, v.303, p.212-218, 2003.

BROWN, E.G.; VANDEHAAR, M.J.; DANIELS, K.M. et al. Effect of increasing energy and protein intake on body growth and carcass composition of heifer calves. Journal of Dairy Science, v.88, p.584-594, 2005.

CLEVELAND, W.S.; GROSSE, E. Computational methods for local regression. Statistics and Computing, v.1, p.47-62, 1991

COHEN, P.; GRAVES, H.C.; PEEHL, D.M. et al. Prostate-specific antigen (PSA) is an insulin-like growth factor binding protein3 protease found in seminal plasma. Journal of Clinical Endocrinology \& Metabolism, v.75, p.1046-1053, 1992.

DAVIS RINCKER, L.E.; WEBER NIELSEN, M.S.; CHAPIN, L.T. et al. Effects of feeding prepubertal heifers a high-energy diet for three, six, or twelve weeks on feed intake, body growth, and fat deposition. Journal of Dairy Science, v.91, p.1913-1925, 2008.

FENTON, J.W. Thrombin. New York Academy of Sciences, v.485, p.5-15, 1986.

FORSYTH, I. A. Growth factors in mammary gland function. Journal of Reproduction and Fertility, v.85, p.759-770, 1989.

HUYNH, H.; YANG, X.; POLLAK, M. Estradiol and antiestrogens regulate a growth inhibitory insulin-like growth factor binding protein-3 autocrine loop in human breast cancer cells. The Journal of Biological Chemistry, v.271, p.1016-1021, 1996.

ILAN, N.; CHEUNG, L.; MILLER, S. et al. Pecam-1 is a modulator of stat family member phosphorylation and localization: lessons from a transgenic mouse. Developmental Biology, v.232, p.219-232, 2001.

ILAN, N.; MADRI, J.A. PECAM-1: old friend, new partners. Current Opinion in Cell Biology, v.15, p.515-524, 2003.

MOTOKURA, T.; BLOOM, T.; KIM, H.G. et al., A novel cyclin encoded by a bcll-linked candidate oncogene. Nature, v.350, p.512-515, 1991.

NEMADE, R.V.; BIERIE, B.; NOZAWA, M. et al. Biogenesis and function of mouse mammary epithelium depends on the presence of functional $\alpha$-catenin. Mechanisms of Development, v.121, p.91-99, 2004.

RADCLIFF, R.P.; VANDEHAAR, M.J.; CHAPIN, L.T. et al. Effects of diet and injection of bovine somatotropin on prepubertal growth 
and first-lactation milk yields of Holstein cows. Journal of Dairy Science, v.83, p.23-29, 2000.

RADCLIFF, R.P.; VANDEHAAR, M.J.; KOBAYASHI, Y. et al. Effect of dietary energy and somatotropin on components of the somatotropic axis in Holstein heifers. Journal of Dairy Science, v.87, p.1229-1235, 2004.

RADCLIFF, R.P.; VANDEHAAR, M.J.; SKIDMORE, A.L. et al. Effects of diet and bovine somatotropin on heifer growth and mammary development. Journal of Dairy Science, v.80, p.1996-2003, 1997.

SAKSELA, O.; RIFKIN, D.B. Cell-associated plasminogen activation: regulation and physiological functions. Annual Review of Cell Biology, v.4, p.93-126, 1988

SEJRSEN, K.; FOLDAGER, J.; SORENSEN, M.T. et al. Effect of exogenous bovine somatotropin on pubertal mammary development in heifers. Journal of Dairy Science, v.69, p.1528-1535, 1986.

SEJRSEN, K.; PURUP, S. Influence of prepubertal feeding level on milk yield potential of dairy heifers: a review. Journal of Animal Science, v.75, p.828-835, 1997.

STEINBERG, M.S. Adhesion in development: an historical overview. Developmental Biology, v.180, p.377-388, 1996.

STOREY, J.D. A direct approach to false discovery rates. Journal of the Royal Statistical: Series B (Statistical Methodology), v.64, p.479-498, 2002.

SUCHYTA, S.P.; SIPKOVSKY, S.; KRUSKA, R. et al. Development and testing of a high-density cDNA microarray resource for cattle. Physiological Genomics, v.15, p.158-164, 2003.
SUTKOWSKI, D.M.; GOODE, R.L.; BANIEL, J. et al. Growth regulation of prostatic stromal cells by prostate-specific antigen. Journal of National Cancer Institute, v.91, p.1663-1669, 1999.

TORRES-ROSADO, A.; O'SHEA, K.S.; TSUJI, A. et al. Hepsin, a putative cell-surface serine protease, is required for mammalian cell growth. Proceedings of the National Academy of Science, v.90, p.7181-7185, 1993.

TSUJI, A.; TORRES-ROSADO, A.; ARAI, T. et al. Hepsin, a cell membrane-associated protease: characterization, tissue distribution, and gene localization. The Journal of Biological Chemistry, v.266, p.16948-16953, 1991.

VASIOUKHIN, V.; BAUER, C.; DEGENSTEIN, L. et al. Hyperproliferation and defects in epidermal polarity upon conditional ablation of a-catenin in skin. Cell, v.104, p.605-617, 2001.

VESTERGAARD, M.; SEJRSEN, K.; FOLDAGER, J. et al. The effect of bovine growth hormone on growth, carcass composition, and meat quality of dairy heifers. Acta Agriculturae Scandinavica, v.43, p.165-172, 1993.

VU, T.K.; WHEATON, V.I.; HUNG, D.T. et al. Domains specifying thrombin-receptor interaction. Nature, v.353, p.674-677, 1991.

WOLFINGER, R.D.; GIBSON, G.; WOLFINGER, E.D. et al. Assessing gene significance from cDNA microarray expression data via mixed models. Journal of Computational Biology, v.8, p.625-637, 2001.

YANG, Y.H.; DUDOIT, S.; LUU, P. et al. Normalization for cDNA microarray data: A robust composite method addressing single and multiple slide systematic variation. Nucleic Acids Research, v.30, p.1-10, 2002. 